\title{
A - Descriptive Study To Assess The Level Of Anxiety And Coping Strategies Among Th.e Patients Admitted In Intensive Care Unit
}

\section{*G.Umamaheswari}

\begin{abstract}
objectives- To assess the coping strategies among the patients admitted in intensive care unit and to correlate the level of anxiety and coping strategies. MethodDescriptive design was found to be relevant for. this study with purposive sampling technique. Result-The results regarding the level of anxiety 2(6.6\%) patient's perceived mild anxiety, 15(50\%) patient's perceived moderate anxiety und $13(43.3 \%)$ patient's per-ceived severe anxiety. Regarding the coping strategies 2(6.6\%) patients had good coping and 15(50\%) had moderate coping and 13(43.3\%) had poor coping; Conclusion-The study Coping positively will aid in better prognosis.
\end{abstract}

Keywords: Anxiety, Coping Strategies.

\section{Introduction}

The frightening experience in intensive care unit, whether it be associated with the disease process or related to the intensive care environment has an important impact on clients recovery and rehabilitation that needs good coping - effortsfor the better prognosis. The glpbat literature evinces that the Intensive Care Unit (ICU) is a stressful place, where patient experiences physical and psychological discomfort due to the environment characterized by a large amount of equipment, professional and procedures.

Anxiety evolves act of life' events and experiences stimulates one's thinking process and helps to maintain a basal level of autonomic arousal, anxiety and certain behavior.

\section{Objectives}

- To assess the level of anxiety among the patients admitted in intensive care unit.

- To assess the coping strategies among the patients admitted in intensive care unit.

- To correlate the level of anxiety and coping strategies.

- To find out the association between anxiety and selected demographic

- To find out the association between coping and selected demographicvariables.

\section{Methodology}

Descriptive design based on the survey approach was used. The study was conducted at Government Hospital at Virudhunagar. The population consisted of patients admitted in intensive care 
unit The sample consisted of 30 patients.

The .st udy was conducted over a period of two weeks using purposive sampling technique. Every day of an average of 2-3 subjects were selected by purposive method.

\section{Inclusion criteria}

- Patients between the age of $30-59$ years

- Patients admitted in Intensive care unit for a minimum of 24 hrs.

- Patients who were able to communicate.

Exclusion criteria

- Patients who had a history of psychosis and neurological deficits.

- Distorted cognitive functions with possible altered perception.

\section{Description of the tool}

1. The demographic variables of the patients admitted in intensive care unit.

2. State trait anxiety inventory scale to assess the level of anxiety among the patients admitted in intensive care unit.

3. Lazarus Coping inventory scale to assess the coping strategies among the patients admitted in intensive care unit.

\section{Findings}

Frequency distribution of samples according to their level of anxiety $N=30$

\begin{tabular}{|l|l|l|l|}
\hline Category & $\begin{array}{l}\text { Range of } \\
\text { score }\end{array}$ & $\mathrm{N}$ & $\%$ \\
\hline $\begin{array}{l}\text { Mild } \\
\text { anxiety }\end{array}$ & $21-40$ & 2 & $6.6 \%$ \\
\hline $\begin{array}{l}\text { Moderate } \\
\text { anxiety }\end{array}$ & $41-60$ & 15 & $50 \%$ \\
\hline $\begin{array}{l}\text { Severe } \\
\text { anxiety }\end{array}$ & $61-80$ & 13 & $43.3 \%$ \\
\hline
\end{tabular}

Table-1: Numerically depicts thedistribution of samples according to theiranxiety scores. $2(6.6 \%)$ patientsperceived mild anxiety, $15(50 \%)$ patients
Perceived13(43.3\%)anxiety.moderate anxiety andpatients perceived severe Distribution of samples according to their coping strategies $\mathrm{N}=30$

\begin{tabular}{|l|l|l|l|}
\hline Category & $\begin{array}{l}\text { Range of } \\
\text { score }\end{array}$ & $\mathrm{N}$ & $\%$ \\
\hline $\begin{array}{l}\text { Good } \\
\text { coping }\end{array}$ & $21-40$ & 2 & $6.6 \%$ \\
\hline $\begin{array}{l}\text { Moderate } \\
\text { coping }\end{array}$ & $41-60$ & 15 & $50 \%$ \\
\hline $\begin{array}{l}\text { Poor } \\
\text { coping }\end{array}$ & $61-80$ & 13 & $43.3 \%$ \\
\hline
\end{tabular}

Table-2 portrays that 2(6.6\%) patientshad good copingand 15(50\%) hadmoderate coping and $13(43.3 \%)$ had poorcoping.

Correlation between perceived anxiety andcoping strategies among patients admitted inIntensive Care Unit

\begin{tabular}{|l|l|l|l|l|l|}
\hline S.no & Category & Mean & SD & C & S \\
\hline 1 & $\begin{array}{l}\text { Anxiety } \\
\text { score }\end{array}$ & 57 & 6 & 0.56 & 0.05 \\
\cline { 1 - 4 } & $\begin{array}{l}\text { Coping } \\
\text { score }\end{array}$ & 37.7 & 10 & & \\
\hline
\end{tabular}

Table-3: Correlation ' $r$ ' value wascomputed between the variable indicated in table 3 . It is observed that thecorrelation exists between anxiety andcoping strategies of patients admitted inIntensive Care Unit. The score isindicating a moderate positiverelationship as the ' $r$ ' value $r=0.56$ whichis significant at 0.05 level.

Level of anxiety and its association with demographic variables.

There was a significant association between the anxiety and selected demographic variable religion and there was no association with other demographic variables like age, sex 
education, occupation, marriage, income, type of family.

\section{Coping strategies and Its association with demographic variables.}

- There was a significant association between coping strategies and selected demographic variables like $\operatorname{sex}(\mathrm{X} 2=13.4)$ and there was no association with age, education, income, type of family, marriage, religion \& occupation.

\section{Recommendations}

- A descriptive study can be done regarding attitude and coping among patients in intensive care unit.

- A study can be undertaken to find out the role of nurse in reducing psychological problems and improving the coping ability of patient in

intensive care unit.

- A study can be conducted to find out the effects of programmed instruction given to the patients regarding the disease condition and treatment in

terms of the anxiety and coping.

\section{Conclusion}

Patients admitted in intensive care unit experience anxiety and extent of this is closely linked to the behavior of thepatient. Coping positively will not onlymake the patients to feel better but alsoaids in better prognosis.

\section{References}

1. Linda D urden (2000). Priorities in critical care nursing, ( 4th edition), California: Mosby publications,429-433.

2.Sailaja busi (2013). Text book of critical care for nurses, (1st edition), newdelhi: PARAS publication,145-146.

3.PK verma (2008). Principles and practice of critical care, (3 rd edition), Newdelhi: 8.1 publications, 316-318.

4.Cynthia c. chernecky (2001). Critical nursing care of the client with cancer, 485501.

5.Mrs.Manjumathew (2011) level of stress among elderly in ICU; 3(6), 12-14.

6.Mr.Jayasebastin (2012) level of anxiety among patient in Neuro ICU, 2(3), 35-37.

7.Sikender kumara (2013) level of stress among patient in ICU, 9(3), 19-20.

8.Sheela teres (2012) fear associated with patient in IMCU; 7(3), 18-22.

9.Prabha k.Dasila (2012), stress in critically ill patient; 8( 4), 30-33. 